\title{
A Viral Revaluation of All Values?
}

\author{
Dany Nobus
}

Trying to find a fitting way to begin this brief reflection, I felt like Leonard Cohen when he sat down to write to Marianne Ihlen in his room at the Penn Terminal Hotel in New York City on 23 February 1967, the day after his first major performance, in front of 3,000 people, at the Village Theatre: "I can hardly write, not because I'm in bad shape, but because there's so much or so little to tell" (Cohen 1967). What is there to tell that has not been told numerous times over, about 'unprecedented times', the 'worst peacetime emergency in living times', the 'war against an invisible enemy', 'underlying health conditions', '(the persistent lack of) personal protective equipment', 'social distancing'? What is there to tell when so many words of love, life and death have been blunted by routine usage to such an extent that they cannot possibly be used anymore to relay the singular authenticity of a lived, subjective experience? So much to tell because, quite paradoxically, being in lockdown has sparked a surfeit of new intractable experiences. So little to tell because, quite paradoxically, all distinctly unique, internal experiences have become homogenised in a global, collective experiential life-world.

So when and where did it all begin? I cannot remember exactly when I first heard about COVID-19, yet it was undoubtedly quite some time after it was first diagnosed and quite some time before it became almost impossible to hear about anything else. Scientists around the world are reportedly working exceptionally hard to establish the precise origin of the virus, in order to be better equipped to prevent the next pandemic (Readfearn 2020). On the 
surface, this seems like a perfectly sound kind of reasoning- "An ounce of prevention is worth a pound of cure", the $13^{\text {th }}$ Century English jurist Henry de Bracton once said-yet unfortunately it also includes a highly uncomfortable truth about the limits and limitations of human life. Were it to be firmly established that patient zero was indeed a Chinese market vendor who unwittingly contracted the virus from an infected bat or pangolin, the only element of truth this zoonotic origin story would contain is that the next pandemic cannot be prevented at all, even if it were driven by an identical viral strain and not to occur for another century or so. Anticipatory and prophylactic health care are not just a function of purportedly evidence-based scientific knowledge about how illnesses happen, diseases spread and epidemics decimate the human population, but also, and much more fundamentally, of how the evidence is manufactured, consolidated and employed. And this assumes that an effective vaccine can be found, which is by no means as indisputable as virologists and epidemiologists would want us to believe. Forty years after the Human Immunodeficiency Virus was properly identified for the first time in humans, and 75 million deaths later, there is still no effective vaccine for HIV.

The intrinsic instability and ineluctable politicisation of scientific knowledge is but one of the great many tensions and truths the question of the virus-which should also be understood, here, as a subjective genitive, and thus as the question posed by the virus-has magnified and laid bare. To be clear, it is not the viral question in itself which has fully exposed some of the most disturbing aspects of $21^{\text {st }}$ century life on planet earth, but the socio-political, institutional and personal responses to it, as if the proverbial truth-inducing properties of the freely flowing 'vino' had been ubiquitously replaced with the equally revealing effects of a rapidly replicating virus. If sickness indeed shows us what we are, then what has thus far already been disclosed is that the human and socio-economic cost of the pandemic will be 
exponentially higher in the neo-liberal, individualist West than in the communitarian East. Some autocratic leaders have undoubtedly capitalised on the Chinese relative success in controlling transmission rates, in order to legitimise and expand their dictatorial rule, which would be another way to illustrate how 'truth is in the virus', yet the Chinese success story is first and foremost an exemplification of the bankruptcy of the value system underpinning Western political economies. In the weeks leading up to the nationwide lockdown of 23 March 2020, the UK government first entertained the 'scientifically proven' theory of herd immunity, presumably because economic wealth should always take precedence over public health, and then exchanged this approach, allegedly because the 'science' had changed, for an explicit reliance on the general public's individual goodwill to respect the rules of social distancing. Only when it was observed that this individual goodwill was not nearly as reliable as politicians had thought it to be, and that public health (systems) could potentially be put at an even higher risk than under herd immunity strategies, did the perspective change from a recommendation to an imposition. It is important to note, however, that the European (and American) models of containment are not a latter-day replication of the Chinese (and South Korean) approaches, which have gone much further in curtailing individual liberties, and that any such replication, were it to be deemed acceptable, would always already be too little too late. Strange as it may seem, the staggering human and economic cost of the virus in the West is directly proportional to its spurious ideological belief in the productive power of selfgovernance and individual enterprise.

There are numerous other examples of how the global pandemic has ruthlessly exposed the fissures, fractures and fragilities of human civilization, from hidden or neglected social inequalities to painfully inadequate health care systems, and from the purportedly unassailable health economic principle of cost-effectiveness to personal health as a measure 
of social status. In this respect, the virus does discriminate, because Black and Minority Ethnic people are significantly more likely to contract it and subsequently die from COVID-19 than other sections of the population (Lynch 2020). In this respect, the current global war against the invisible enemy does not just exist in the general population and in hospitals, but also (and much more surreptitiously) in the great many public and private care homes for the elderly and other vulnerable citizens. In this respect, working from home to protect oneself, one's neighbours, and the healthcare system is not just a general rule that can be rolled-out indiscriminately to everyone (apart from the so-called 'key-workers'), but a concrete professional practice whose successful implementation not only depends on the flexibility of the employer and the creativity of the worker, but most crucially on the 'level' of the work undertaken, and thus on social status.

It is far too early to tell whether the pandemic will lead to a complete 'revaluation of all values', along the lines Nietzsche called for, although in his case as a radical alternative to the Christian "immortal blot on humanity" (Nietzsche 1888, p. 66) rather than the equally invincible rise of global capitalism. In a thoughtful piece on the impact of the coronavirus on climate change, which moved far beyond the platitudes of 'nature steadily bouncing back' in the now largely deserted areas of former human pollution, Arthur Wyns, a researcher working for the World Health Organization, recently argued that the pandemic may very well elicit a more profound appreciation of our vulnerabilities and of the global ties that bind us, which may in turn generate a better understanding of the most important threat to our human survival, i.e. the climate crisis (Wyns 2020). Pessimist as I am, and uplifting as the statement may be, I remain unsure whether this message of hope will come to pass. There is little doubt that Western economies will need a long time to recover from the as yet immeasurable damage that has been inflicted upon all the constitutive organs of its supposedly resilient 
body. There is little doubt that historical time will be punctuated by a 'before' and an 'after corona', and that our collective memories will be forever tainted by the time when the world stood still. Yet none of this implies that the recovery process will also entail a radical revision of the value systems which, if they cannot be held responsible for a Chinese market vendor interacting with a bat or pangolin, can definitely to some extent be held to account for the ongoing transmission of a lethal virus and the hundreds of thousands of deaths it has carried in its wake. For a viral revaluation of all values to happen, maybe the pandemic will have ended too soon, much like, in Freud's infamous words to his Hungarian colleague Sándor Ferenczi, World War I effectively ended to soon for psychiatry to become de-stabilised and psychoanalysis to benefit from the collapse of its scientific hegemony (Falzeder, Brabant \& Giampieri-Deutsch 1996, p. 311). Maybe in 500 years, historians will look back upon the year 2020 as the beginning of the second Renaissance; maybe in 500 years, 2020 will merely be recorded as an extremely significant, yet ultimately controlled disruption in the course of human existence.

London, 15 April 2020 


\section{REFERENCES}

Cohen, L. (1967). Letter to Marianne Ihlen of 23 February 1967. Private Collection.

Falzeder, E., Brabant, E. \& Giampieri-Deutsch, P. (Eds) (1996). The Correspondence of Sigmund Freud and Sándor Ferenczi. Vol. 2: 1914-1919. transl. P. T. Hoffer. Cambridge MALondon: The Belknap Press of Harvard University Press.

Lynch, C. (2020). "Coronavirus: Black and Hispanic People 'twice as likely to die' in US from COVID-19". https://news.sky.com/story/coronavirus-black-and-hispanic-people-twiceas-likely-to-die-in-us-from-covid-19-11971690. Accessed on 14 April 2020.

Nietzsche, F. (1888). The Anti-Christ: A Curse on Christianity. In The Anti-Christ, Ecce Homo, Twilight of the idols, and Other Writings. ed. A. Ridley \& J. Norman, transl. J. Norman. Cambridge: Cambridge University Press, 2005, pp. 1-67.

Readfearn, G. (2020). “How Did Coronavirus Start and Where Did It Come From? Was It Really Wuhan's Animal Market?". https://www.theguardian.com/world/2020/apr/15/howdid-the-coronavirus-start-where-did-it-come-from-how-did-it-spread-humans-was-itreally-bats-pangolins-wuhan-animal-market. Accessed on 14 April 2020.

Wyns, A. (2020). "How Our Responses to Climate Change and the Coronavirus Are Linked". https://www.weforum.org/agenda/2020/04/climate-change-coronavirus-linked/. Accessed on 14 April 2020. 